\title{
PENGARUH PANJANG PIPA KATALIS PADA HCS (HYDROCARBON CRACKING SYSTEM) TERHADAP PERFORMA MOTOR BAKAR 4-LANGKAH
}

\author{
Danang Yudistiro ${ }^{1}$, Nasrul Ilminnafik ${ }^{1}$, Masruri Wardhana ${ }^{2}$ \\ ${ }^{1}$ Staf Pengajar Teknik Mesin Fakultas Teknik Universitas Jember \\ ${ }^{2}$ Mahasiswa Teknik Mesin Fakultas Teknik Universitas Jember \\ E-mail : danang.ft@unej.ac.id
}

Naskah diterima: 29 Nopember 2017 ; Naskah disetujui: 28 Desember 2017

\begin{abstract}
ABSTRAK
HCS (Hydrocarbon Cracking System) merupakan suatu inovasi untuk meningkatkan torsi dan daya bakar. dengan pipa katalis tembaga yang digunakan sebagai alat untuk mempercepat proses cracking bahan bakar yang masuk pada ruang bakar. Penelitian ini bertujuan untuk memperoleh data perbandingan unjuk kerja motor bakar 4 langkah dengan variasi panjang pipa katalis dengan kondisi standarts sebagai pembanding.dalam penelitian dilakukan dengan pengujian yaitu torsi. Dari hasil penelitian yang dilakukan Daya maksimal motor terjadi pada kondisi tanpa katalis dengan nilai 11.9 Hp pada putaran mesin 9552 rpm, sedangkan dengan penambahan daya mengalami penurunan karena bahan bakar yang masuk pada ruang bahan tidak sepenuhnya berbentuk cair sehingga penurunan efisiensi volumetrik juga disebabkan karena volume bahan bakar yang dibutuhkan lebih besar dalam campuran asupan. Nilai torsi mengalami peningkatan dengan penggunaan pipa katalis, torsi teringgi terjadi pada kondisi pipa katalis dengan panjang $200 \mathrm{~mm}$ dengan torsi sebesar 9,32 Nm pada RPM 3040. Untuk katalis dengan panjang $150 \mathrm{~mm}$ dan $100 \mathrm{~mm}$ nilai torsi yang didapat adalah 9,23 Nm dan 9,16 $\mathrm{Nm}$, sedangakan pada kondisi standart torsi hanya 9,13 Nm. Proses cracking akan terjadi pemecahan molekul - molekul senyawa hidrokarbon yang besar menjadi molekul - molekul senyawa yang lebih kecil, sehingga adanya proses craking tersebut membuat campuran bahan bakar dan udara menjadi lebih ideal dan mudah terbakar pada ruang bakar. Dengan komposisi bahan bakar yang ideal akan meningkatkan pembakaran dan nilai torsi maksimum.
\end{abstract}

Kata Kunci: HCS, Performa, Cracking System, Panjang Katalis

\section{PENDAHULUAN}

Laju pertumbuhan sepeda motor di Indonesia merupakan yang tertinggi di Asean, yakni 13,2\% dibanding moda transportasi lainnya. Dampak dari tingginya jumlah kendaraan adalah konsumsi akan bahan bakar akan meningkat juga. Bahan bakar juga akan mempengaruhi performa yang dihasilkan motor. Pada kenyataanya Semakin tinggi kecepatan motor maka semakin besar pula laju konsumsi bahan bakar yang digunakan[1]. Bahan bakar sangat berpengaruh terhadap kinerja dan perfomance kendaraan. Kandungan nilai oktan dalam bahan bakar minyak juga mempengaruhi kinerja dan performance sepeda motor. Selain meningkatan performa mesin, nilai oktan sangat berpengaruh signifikan terhadap karakterisitik emisi gas buang [2].

Nilai oktan tinggi dan rasio kompresi tinggi memperoleh efisiensi yang optimal tanpa detonasi (knocking) dan pembakaran menjadi sempurna. Pengunaan bahan bakar dengan angka oktan yang sesuai juga sangat mempengaruhi kinerja dari kendaraan. Angka oktan tinggi cocok untuk perbandingan kompresi yang tinggi untuk memperoleh efisiensi tinggi [3]. Maka dari itu perlu adanya campuran bahan yang sempurna dengan oktan yang memenuhi, sehingga pembakaran dapat berlangsung mendekati ideal.

Penggunaan HCS sistem memecah atom hidrokarbon menjadi atom hidrogen $(\mathrm{H})$ dan karbon $(\mathrm{C})$ dengan cara menggunakan pipa katalis yang dipanaskan[4]. Menjadikan kandungan bahan bakar memiliki nilai oktan tinggi, daya mesin yang lebih besar dan konsumsi bahan bakar rendah [5]. HCS sangat efektif dalam mereduksi emisi gas buang yang dihasilkan oleh kendaraan bermotor. Karena supplay uap dari hasil reaksi bahan bakar yang digunakan sehingga meningkatkan proses pembakaran yang pada ruang bakar, nilai oktan dan campuran bahan bakar sangat berpengaruh 
terhadap hasil pembakaran. Dengan penambahan hidrogen pada bahan bakar maka proses pembakaran menjadi lebih sempurna.

Dari beberapa permasalahan dan uraian di atas dapat dijadikan sumber oleh peneliti dalam melakukan penelitian dengan memanfaatkan sistem Hydrocarbon Crack System (HCS). Dengan variasi panjang pipa katalis Hydrocarbon Crack System (HCS) dengan bentuk annulus konsentris. Sehingga dapat menghasilkan performa motor yang maksimal.

\section{METODOLOGI}

\section{Dynamic Vibration Absorber (DVA)}

Metode Penelitian yang digunakan adalah eksperimental yaitu suatu metode yang digunakan untuk membandingkan pengujian beberapa variasi perlakuan dengan pengujian tanpa variasi sebagai pembanding.

\section{Variabel Penelitian}

Variabel Bebas

Variabel bebas yaitu variabel yang bebas ditentukan oleh peneliti dalam rangka untuk menerangkan hubungannya dengan fenomena yang diobservasi. Variabel bebas yang digunakan dalam penelitian ini adalah dengan panjang dari pipa katalis annulus konsentris $100 \mathrm{~mm}, 150 \mathrm{~mm}$, dan $200 \mathrm{~mm}$. untuk variasi bebas kedua adalah kecepatan putaran mesin pada 3000 $\mathrm{rpm}, 4000 \mathrm{rpm}, 5000 \mathrm{rpm}, 6000 \mathrm{rpm}$, dan $7000 \mathrm{rpm}$, sesuai dengan spesifikasi putaran maksimum motor, rentan minimum alat uji.dengan bakar pertalite dan suhu konstan pada $200^{\circ} \mathrm{C}$.

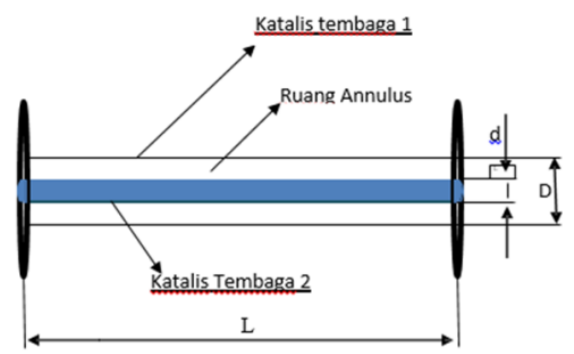

Gambar 1 desain pipa katalis annulus konsentris.

Variabel Terikat

Merupakan variabel yang besaranya tidak dapat ditentukan sepenuhnya oleh peneliti, tetapi besarannya tergantung dengan variabel bebasnya. Variabel terikat dalam penelitian kali ini adalah:

a. Torsi Maksimal

b. Daya Maksimal
Skema Instalasi HCS (Hydrokarbon Cracking System)

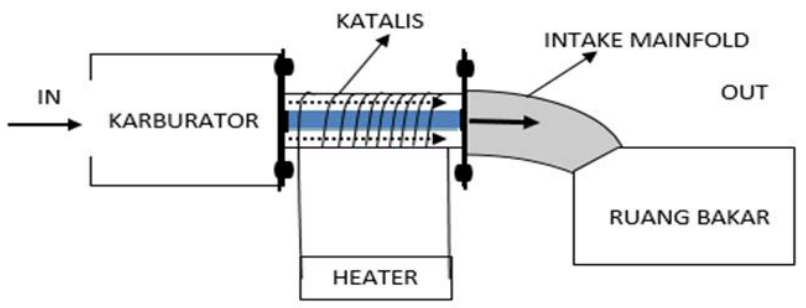

HASIL DAN PEMBAHASAN

a. Torsi Maksimum

Tabel 1 Tabel hasil pengujian torsi maksimum

\begin{tabular}{|c|c|c|}
\hline PANJANG KATALIS $(\mathrm{mm})$ & TORSI MAX (N.m) & PUTARANMESIN (RPM) \\
\hline 50 & 9.13 & 4555 \\
\hline 100 & 9.26 & 3892 \\
\hline 150 & 9.23 & 3874 \\
\hline 200 & 9.32 & 3040 \\
\hline
\end{tabular}

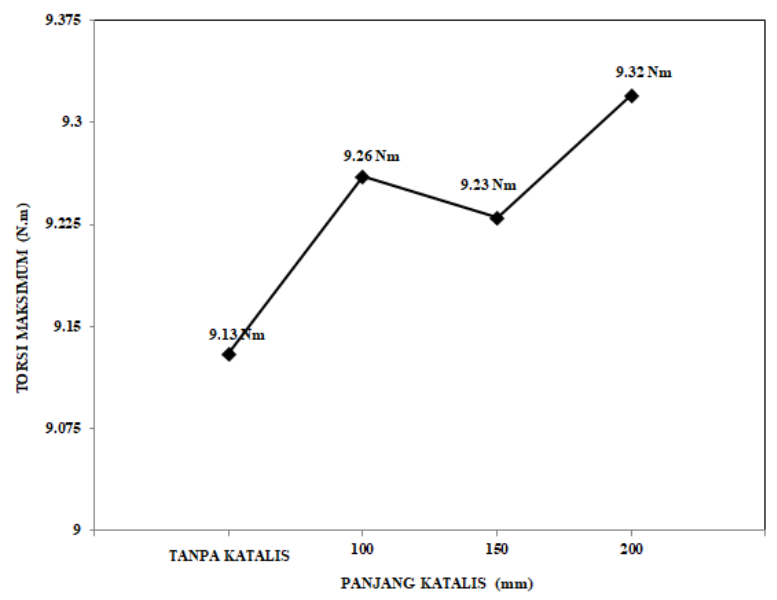

Gambar 2 Grafik Pengaruh Panjang Katalis Terhadap Torsi

Pada Gambar 2 dapat dilihat torsi tertinggi terdapat pada saat penggunaan pipa katalis dengan ukuran $200 \mathrm{~mm}$, menunjukan torsi pada angka 9,32 $\mathrm{Nm}$ pada putaran mesin $3040 \mathrm{rpm}$. Penggunaan katalis dengan panjang $200 \mathrm{~mm}$ menghasilkan torsi tertinggi dibandingkan dengan tanpa menggunakan katalis (standart) yang hanya mencapai torsi maksimal sebesar 9,13 Nm. Pada katalis panjang $150 \mathrm{~mm}$ mampu menghasilkan torsi maksimum 9,23 Nm pada rpm 3874 dan untuk katalis $100 \mathrm{~mm}$ mampu mendapatkan torsi maksimum 9,26 Nm pada putaran mesin sebesar $3892 \mathrm{rpm}$.

Pada Gambar 2 menunjukan pengaruh panjang pipa katalis pada sistem HCS memberikan pengaruh pada 
peningkatan nilai torsi maksimu pada sebuah kendaraan. Kenaikan nilai torsi pada penambahan panjang dikarenakan adanya proses cracking pada bahan bakar sebelum masuk kedalam ruang bakar. Proses cracking pada pipa katalis menyebabkan $\mathrm{CH}$ pada bahan bakar terpecah sehingga menjad atom $\mathrm{C}$ dan $\mathrm{H}$, dengan adanya atom $\mathrm{H}$ pada bahan bakar maka campuran bahan bakar akan menjadi lebih ideal dan mudah terbakar pada ruang bakar. Proses cracking pada katalis juga akan akan mempengaruhi campuran bahan bakar sehingga bahan bakar akan lebih mudah mengikat oksigen. Panjang pipa katalis akan meningkatkan jumlah hidrokarbon dan kemurnian hidrogen dan karbon tanpa kandungan $\mathrm{H} 2 \mathrm{O}$ [6]. Dengan adanya penambahan hydrogen hasil cracking pada katalis dan komposisi bahan bakar yang ideal, maka pembakaran akan mendekati ideal. Pembakaran yang ideal akan meningkatkan torsi pada kendaraan.

\section{b. Daya Maksimum}

Tabel 2 Tabel hasil pengujian daya maksimum

\begin{tabular}{|c|c|c|}
\hline PANJANG KATALIS (mm) & DAYA MAX (Hp) & PUTARAN MESIN (RPM) \\
\hline TANPA KATALIS & 11.9 & 9552 \\
\hline 100 & 11.11 & 8967 \\
\hline 150 & 11.78 & 9485 \\
\hline 200 & 11.89 & 9547 \\
\hline
\end{tabular}

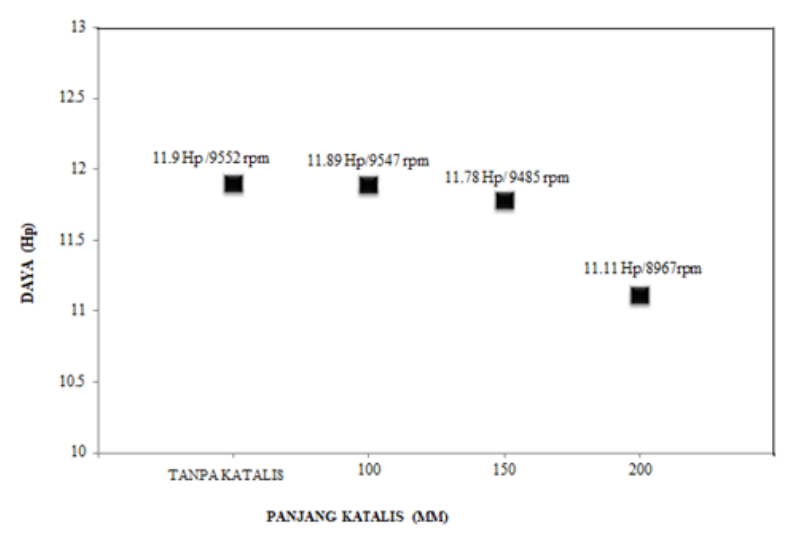

Gambar 3 Grafik Pengaruh Panjang Katalis Terhadap Torsi

Pada Gambar 3 terlihat Daya merupakan ukuran untuk menentukan besarnya kerja motor yang dapat dilakukan dalam priode waktu tertentu. Pada gambar 4.2 dapat dilihat bahwa daya terbesar terjadi pada kondisi tanpa pengunaan katalis dengan daya 11,9 Hp pada putaran mesin $9552 \mathrm{rpm}$. Pada kondisi ini daya yang dihasilkan oleh perlakuan tanpa penambahan katalis lebih besar dari pada penambahan pipa katalis. Hal ini disebabkan karena pada penambahan pipa katalis bahan bakar yang masuk pada ruang bahan tidak sepenuhnya berbentuk cair sehingga penurunan efisiensi.

Pada Gambar 3 menunjukan bahwa daya terbesar dengan penambahan pipa katalis terjadi pada kondisi pipa katalis $100 \mathrm{~mm}$ dengan daya sebesar 11,89 Hp. Sedangkan pada pipa katalis $150 \mathrm{~mm}$ dan $200 \mathrm{~mm}$ daya maksimum hanya pada $11,78 \mathrm{Hp}$ dan $11,11 \mathrm{Hp}$ pada putaran mesin masing - masing $9485 \mathrm{rpm}$ dan $8967 \mathrm{rpm}$. Hal tersebut menunjukan bahwa panjang pipa katalis menurunkan nilai daya yang dihasilkan, pada proses campuran bahan bakar yang masuk pada ruang bakar tidak sesuai dengan komposisi bahan bakar yang sesuai dengan kompresi mesin kendaaraan sehingga daya menurun.

\section{KESIMPULAN}

Berdasar analisis dan data-data yang diperoleh dari hasil pengujian dapat diambil kesimpulan sebagai berikut:

1. Penambahan pipa katalis dapat meningkatkan nilai torsi kendaraan, dengan penambahan panjang katalis $200 \mathrm{~mm}$ dapat mengahasilkan torsi paling optimal.

2. Dari hasil pengujian daya paling efisien terdapat pada kondisi dtandart, dengan nilai 11.9 pada putaran mesin $9552 \mathrm{rpm}$.

\section{DAFTAR PUSTAKA}

[1] Gunawan, H., R. Fernando., dan G. Nyoman. 2013. Analisis Konsumsi Bahan Bakar Motor Bensin Yang Terpasang Pada Sepeda Motor Suzuki Smash 110cc Yang Digunakan Pada Jalan Menanjak. Jurusan Teknik Mesin, Universitas Sam Ratulangi

[2] Negara, S., I. W. S. Budiarsa., dan I. W. Suarna. 2009. Pengaruh Nilai Oktan Bahan Bakar Dan Putaran Mesin Pada Kendaraan Bermotor Terhadap Karakteristik Emisi Gas Buang. Jurnal Ecotrophic. 4(2):106-111.

[3] Arismunandar, Wiranto. 2002. Penggerak Mula Motor Bakar Torak. Edisi Kelima. Bandung: ITB

[4] Sukarmin. 2004. Hidrokarbon dan Minyak Bumi., Departemen Pendidikan Nasional Indonsia. Kim. 13

[5] Supraptono, 2004., Bahan Bakar dan Pelumas., Teknik Mesin Fakultas Teknik Universitas Negeri Semarang.

[6] Rahardjo Tirtoatmodjo. 2009. Pemanfaatan Energi Gas Buang Motor Diesel Stasioner untuk Pemanas Air., Jurnal Teknik Mesin Vol. 1, No. 1 : 24 - 29. Jurusan Teknik Mesin, Fakultas Teknologi Industri, Universitas Kristen 